Maurer School of Law: Indiana University

Digital Repository@Maurer Law

Indiana Law Journal

Volume 39 | Issue 3

Article 2

Spring 1964

\title{
The Role of Domestic Courts in the International Legal Order
}

Richard A. Falk

Princeton University

Follow this and additional works at: https://www.repository.law.indiana.edu/ilj

Part of the Courts Commons, and the International Law Commons

\section{Recommended Citation}

Falk, Richard A. (1964) "The Role of Domestic Courts in the International Legal Order," Indiana Law Journal: Vol. 39 : Iss. 3 , Article 2.

Available at: https://www.repository.law.indiana.edu/ilj/vol39/iss3/2

This Symposium is brought to you for free and open access by the Law School Journals at Digital Repository @ Maurer Law. It has been accepted for inclusion in Indiana Law Journal by an authorized editor of Digital Repository@ Maurer Law. For more information, please contact rvaughan@indiana.edu.

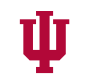

JEROME HALL LAW LIBRARY

INDIANA UNIVERSITY

Maurer School of Law
Blooming ton 


\title{
THE ROLE OF DOMESTIC COURTS IN THE INTERNATIONAL LEGAL ORDER*
}

\author{
RICHARD A. FALK†
}

The Banco Nacional de Cuba v. Sabbatino litigation has encouraged speculation about the proper role of domestic courts in the international legal order. ${ }^{2}$ In this article the accent is upon the proper response of a court in the United States to the argument that the official action of a foreign government is, in some sense, illegal. Such a setting emphasizes the manner in which legal authority is and should be allocated between the executive and judicial branches of government in an international law case, i.e., one involving the review of a foreign act of state. This inquiry may help to create a framework of thought that permits a more informed judgment about the most favorable type of participation by an American domestic court in the international legal order. ${ }^{3}$

\section{Some Issues Stated}

The widespread controversy about the role of domestic courts in international law cases centers primarily upon the extent to which courts should be independent of executive supervision in cases that may impinge upon the conduct of foreign relations. A second disagreement concerns the stability of substantive rules of international law in the broad area of state responsibility for injury to alien interests. This article takes a partisan position by supporting judicial independence and by assuming, though not here contending, that many of the traditional rules governing state responsibility are now obsolete. ${ }^{4}$

* I wish to thank Barbara Yount for the customary excellence of her editorial assistance and the Center of International Studies of Princeton University for providing me with its fine research facilities.

$\uparrow$ Associate Professor of International Law, Department of Politics, Woodrow Wilson School of Public and International Affairs; Faculty Associate, Center of International Studies, Princeton University.

1. 307 F.2d 845 (2d Cir. 1962), cert. granted, 376 U.S. 378 (1964), affirming 193 F. Supp. 375 (S.D.N.Y. 1961).

2. See especially Dawson \& Weston, Banco Nacional de Cuba v. Sabbatino: New Wine int Old Bottles, 31 U. CHI. L. Rev. 63 (1936) ; Domke \& Baade, Nationalization of Forcign-Owned Property and the Act of State Doctrine-Two Speeches, 1963 Duke L.J. 296; Lillich, A Pyrrhic Victory at Foley Square; The Second Circuit and Sabbatino, 8 VILL. L. REv. 155 (1963) ; Metzger, The Act of State Doctrine and Foreign Relations, 23 U. PIrT. L. REv. S81 (1962) ; Stevenson, The Sabbatino Case-Three Steps Forward and Two Steps Back, 57 Axr. J. INT'L L. 97 (1963).

3. A more complete attempt to develop a framework for thought about these problems is contained in the forthcoming book FALK, DoMrestic Courts AND INTERNATIONAL, LEGAL ORDER, to be published in June 1964 by the Syracuse University Press.

4. For an excellent analysis of the question of substantive obsolescence in the Sabbatino context, see Dawson \& Weston, supra note 2. 
Analysis of these issues is confined to the perspective of the United States, and for several reasons such a narrowing of perspective deprives the analysis of generality. The character of American political institutions and traditions undoubtedly influences the interpretation. The federal nature of the United States has led to the idea of dual sovereignty for domestic governance; this creates special difficulties for the United States (and for other federal states with non-authoritarian political structures) insofar as the maintenance of unified policies is considered desirable and necessary for a state that participates in international affairs as a sovereign actor. In addition, the traditional doctrine of separation of powers causes Americans to have a set of expectations about the character of judicial independence that, if disappointed, undermines their respect for court proceedings and for the sanctity of law in general. Executive interference in the activities of domestic courts because a legal dispute involves the application of rules of international law is an evident discrimination against this kind of law-a discrimination that might be expected to weaken public confidence in the viability of international law. It is true, of course, that the executive branch is responsible for the conduct of foreign relations, and that foreign relations may be affected by domestic litigation. But should the dictates of foreign relations dominate a private dispute between litigants seeking a vindication of their legal rights by an appeal to rules of private and public international law?

If the litigation involves a public prosecution by the forum state, quite a different issue is presented since a discretionary element enters into the decision to prosecute and a punitive element attaches to a conviction. Therefore, if the defendant in a criminal prosecution is closely identified with the activities or policies of a foreign state, the domestic government needs the authority to terminate the case. But does this suggest that a private party who is injured by the action of a foreign government should be prevented from a remedy in law to the extent that the requisites of jurisdiction can be satisfied? If so, why? A refusal to allow prosecution of the civil remedy on the basis of diplomatic considerations undermines the basic dignity of individual rights, for then the domestic authority is exercised to subordinate private rights to some hypothetical public interest. Especially in a democratic society, it is important to preserve the private sector and to resist the encroachments of government. Access to courts is symbolic of the right of a free individual. The paternalistic claim that the government can protect its citizens better if they are denied a judicial remedy in an international law case is not only unnecessary, but undermines the effort to transform the law of 
nations into a law of mankind. ${ }^{5}$

Eventually we need to disentangle what is American from what is universal about the role of domestic courts in the international legal system. Such an operation must await, however, detailed comparative studies of constitutional tradition, political reality and public expectation in the major domestic societies of the world. ${ }^{b}$ In the interim an assessment of the role of domestic courts must necessarily remain partial. Nevertheless, the argument in favor of judicial autonomy can be advanced from an American perspective both to uphold domestic values and traditions and to advance the cause of world legal order. This is not intended as an endorsement of a provincial outlook. Instead it is contended that courts should construe the character of international law from a broadly nonnational perspective.

There are two kinds of autonomy: the autonomy of the judicial institutions within the framework of the domestic political system, and the autonomy of the rules of international law within the law-applying context. The first form of autonomy without the second may be less satisfactory than the elimination of both. A failure to achieve the second form, the impartial application of existing rules of international law, causes the judiciary to be politicized and transforms adjudicative proceedings into ex parte argument. This failure is probably more damaging to the development of international law than the exercise of discretionary control by the executive over the courts in a frankly political fashion. ${ }^{7}$ If a domestic court construes controversial rules of international law to accord with national values, courts become politicized by their own independent action. This causes the content of international law to be more responsive to national interests, leads foreign parties with antagonistic values to expect and receive unfair treatment in a domestic

5. Such a transformation has been suggested, discerned and commended with admirable clarity in Jenks, The Common Law OF MANkind 1-22 (1958).

6. A multi-national inquiry of this sort would allow us to appraise the prospects for integrating domestic courts into a global set of institutions administering a common legal system according to common principles. National societies that have completely centralized political power and have subordinated all law to the demands of politics would not be very likely to permit their domestic courts to develop an autonomous tradition in cases involving international law.

7. Throughout this article a contrast is made between law and politics that can be easily misunderstood. The plea for judicial independence and the arguments against political decision-making are intended to emphasize the difference between executive and judicial behavior. However, it is certainly not suggested at this late day that judges can or should decide difficult cases without recourse to policy considerations, or that judges are immune to political pressures generated by national passions. Certainly not! It is a matter of degree. Courts are normally foreclosed, especially if they are so instructed, and refrain from giving expression to temporary policies, whereas the executive, especially in foreign policy as developed in the American tradition, is frankly pragmatic and ad hoc, making the best of the combination of immediate interests. 
court, and makes judicial outcome depend more upon the values and outlook of the forum than upon the uniform impact of rules of international law on the controversy. That pattern neither renders domestic justice nor promotes international law. Thus, the two forms of autonomy are inextricably bound up with one another in an assessment of the activities of domestic courts.

The issues governing autonomy combine problems of allocating legal competence with problems of construing substantive rules. The initial question is not what is the governing rule but rather who shall supply it; the executive has a primary interest in reaching settlements of a category of disputes involving a conflict of interests among states, whereas the judiciary has a primary commitment to the solution of a specific dispute. To reach an executive settlement, the application of legal rules is only one of several elements that enters into inter-governmental negotiations. No one denies that the executive should use diplomatic techniques to resolve international disputes, or that diplomacy which must search for a settlement according to law is often likely to be futile and dogmatic. Yet recognition of a proper sphere of diplomatic action does not and should not infer that the judicial outcome of specific controversies should be suppressed to avoid interference with the pursuit of diplomatic remedies. The executive branch over-generalized in its brief in the Sabbatino case and argued that a diplomatic settlement is more effective than a judicial settlement-as if one prohibited the other. ${ }^{8}$

In what way is executive disposition more effective? There are two sets of interests, each of which is valid within its proper sphere: (1) the public interest in reaching a settlement on a state-to-state basis, the effect of which settlement might also be of indirect benefit to a class of private claimants, and (2) a private interest in having courts available to determine alleged infringements of individual rights. An assumption that the public interest in a general settlement outweighs the private interest is unwarranted unless one is prepared to dismiss as irrelevant, or at least as trivial, the legal protection that is given to individuals by the rules of international law. The material satisfaction of a maximum number of claimants may not be the broadest interest to be served. The judicial

8. The primary and most satisfactory way to deal with foreign acts of state which violate international law is the exercise of diplomacy. In the absence of an international tribunal with power to settle controversies arising from sovereign acts, it seems evident that the effective and important means for dealing with acts of sovereign states which violate international law is not through sporadic American judicial decisions but through the exercise of diplomatic power by the Executive.

Brief for United States as amicus curiae, p. 28, Banco Nacional de Cuba v. Sabbatino, 376 U.S. 378 (1964), reprinted in 2 InterNational. Legal MAterials 1009, 1018 (1963). 
opportunity to reinforce the expectations of private parties that disputes will be settled according to international legal standards serves a general interest that outweighs the special interests of a class of claimants disadvantaged by the default by a foreign government in a particular instance. Moreover, a judicial settlement exhibits the role of law, as distinct from politics, in the struggle to create a stable system of international remedies, the process of which is valuable as pedagogy.

In a domestic law context, it would not occur to anyone to foreclose a normal judicial remedy available to individuals in order to improve the prospects for general settlement. The effort of the federal government to improve the status of the Negro in Southern states might benefit from federal-state diplomacy, but no one would contend that the dictates of the diplomatic method should be allowed to foreclose the pursuit of a remedy by an individual Negro, even if such a remedy might exacerbate federalstate relations to the extent that a general settlement would be hampered. The President's responsibility for supervising federal-state relations does not generate an incidental power to interfere with the ordinary functioning of federal courts. Thus, why does the President's responsibility for foreign affairs generate an incidental power to prevent normal adjudication? No discernible functional need is served by the assumption of such an incidental power.

\section{The Scope of Executive Discretion in Foreign Affairs:}

\section{The Precedents}

Properly construed, the earlier Supreme Court decisions affirming executive prerogatives in the area of foreign relations are not inconsistent with the advocacy of judicial independence. ${ }^{9}$ United States $v$. CurtissWright Export Corp..$^{10}$ concerns the extent of discretion that Congress may vest in the President to control shipments of private arms from the United States to parties engaged in a foreign war. As the Supreme Court correctly affirmed, "in this vast external realm, with its important, delicate, and manifold problems, the President alone has the power to speak or listen as the representative of the nation."11 This general observation

9. The responsibility of the executive for the conduct of foreign affairs has been frequently affirmed by the courts as a guiding principle. See, e.g., Carter v. Carter Coal Co., 298 U.S. 238, 295 (1935) (and cases there cited) ; Mackenzie v. Howe, 239 U.S. 299, 311 (1915). However, the existence of the principle does not determine the scope of the executive competence. The two principal cases considered in this section support a limitation of scope by reference to the functional requirements of the executive undertaking.

10. 229 U.S. 304 (1936).

11. Id. at 319 . 
was related to the functional needs of the executive for discretion in this kind of factual situation:

It is quite apparent that if, in the maintenance of our international relations, embarrassment-perhaps serious embarrassment-is to be avoided and success for our aims achieved, congressional legislation which is to be made effective through negotiation and inquiry within the international field must often accord the President a degree of discretion and freedom from statutory restriction which would not be admissible were domestic affairs alone involved. ${ }^{12}$

The opinion by Mr. Justice Sutherland went on to stress the President's need to rely on "confidential sources of information" to assess the foreign situation, the disclosure of which might be harmful. Since the issue in Curtiss-Wright was the governmental regulation of American business to prevent unintended involvement of the nation in foreign wars, either by establishing an American "presence" on one side by the introduction of United States' arms or by interfering with a national aim to restore peace to the area, as a precedent the case suggests that the Constitution allows the legislature to confer wide discretion on the executive when the subject matter, by its very nature, involves foreign relations. But it must be observed that this case presents the extreme instance-the relation between the United States and a foreign war. It teaches us little about the extent to which, if at all, the executive power over foreign relations impinges upon the normal scope of judicial function in civil litigation in international law cases.

The other important Supreme Court case, Chicago \& S. Air Lines v. Waterman S. S. Corp., ${ }^{13}$ likewise confirms the authority of the executive to carry out the specific foreign relations duties that are entrusted to it. In Waterman the issue involved presidential authority to approve certificates of convenience and necessity issued by the $\mathrm{CAB}$ to foreign carriers or for foreign routes. As in Curtiss-Wright, the Supreme Court emphasized the reliance of the President upon intelligence reports to exercise his responsibility of assuring that $\mathrm{CAB}$ action accords with national security. The combination of administrative and executive action is declared unreviewable by the courts, for "it would be intolerable that courts, without the relevant information, should review and perhaps nullify actions of the Executive taken on information properly held secret." " Furthermore,

12. Id at 320. This conclusion is, perhaps, stated in rhetoric that is unnecessarily sweeping, given the character of the case.

13. 333 U.S. 103 (1948).

14. Id. at 111. 
these are "decisions of a kind for which the Judiciary has neither aptitude, facilities nor responsibility and which [have] long been held to belong in the domain of political power not subject to judicial intrusion or inquiry."15 An appropriate claim of executive preemption is raised by this case, since the nature of the disputed question-the propriety of the grant or the denial of the certificate-cannot be decided by judicial techniques without appraising the President's judgment about national security. But does the Waterman holding militate against our affirmation of judicial independence in civil litigation in international law cases? The disputed issue in those cases is quite susceptible to judicial resolution since it requires only an appraisal of the legality or legal effect of a foreign government's conduct. There is only an indirect and most uncertain connection between the civil case and the conduct of foreign relations. From a technical viewpoint, the domestic court is competent; no political ingredient is embedded in that kind of case.

Of course, trends in world politics may make a judicial act relevant to foreign policy. It may be desirable in one situation to avoid a rebuff to France, whereas in another it may be desirable to rebuff Cuba; therefore, an assurance of judicial support may promote the achievement of executive objectives. But this kind of executive interest is based on ad hoc considerations of foreign policy, and if it is allowed to influence judicial behavior, courts will be nationalized without serving any general executive function or without taking account of limits upon judicial competence. There is no regulative principle, as distinct from ad hoc pressure, to justify the executive claim or to explain judicial abdication. In this sense, the executive claim is unlike Curtiss-Wright or Waterman.

The tradition of judicial deference to ad hoc executive policy can be traced to the influence of United States $v$. Pink, ${ }^{16}$ a principal case stand-

15. Ibid.

16. 315 U.S. 203 (1942). The Pink case involved a determination of the effect of diplomatic recognition upon the disposition of some Russian assets located in New York, which the Soviet government had attempted to confiscate by extra-territorial decree. To reestablish good relations, the Soviet Union agreed in the Litvinov Assignment to assign its claims to American-located assets to the United States government. The latter was then expected to use them to satisfy American claims against the Soviet government. By normal rules of conflict of laws, a state court in New York had decided that the Soviet decree, because of its confiscatory nature, was unable to affect ownership of assets physically present in the United States; there being nothing to assign, the assignee acquired nothing more than the assignor possessed. The Supreme Court reversed on broad grounds, stressing executive supremacy in the area of foreign affairs and a consequent judicial duty to carry out the executive will. In Pink this conception of executivejudicial relations was used to hold that, in view of the objectives of our recognition policy, the Litvinov Assignment must be held to transfer the New York assets to the federal government. This gave the Soviet confiscatory decree retroactive validity; such validity, ironically, could only be reached because the Soviet government was unrecognized at the time that it acted. This illustrates the extent of judicial subservience. 
ing for the subordination of judicial outcome to the foreign policy of the moment. While it is proper for judicial deference to arise solely as a consequence of the structural characteristics and functional requirements of the executive's responsibility for foreign relations, it is improper for judicial deference to be a consequence of the vagaries of shifting patterns of foreign policy. In the latter instance, the court can and would decide the issues in dispute, permitting the executive disposition to manipulate judicial behavior to serve a temporary national interest. To hallow the Pink tradition is to erode the prestige and role of domestic courts in the international legal system. The whole problem of executive-judicial relations in international law cases cannot be satisfactorily resolved without a reexamination, and an eventual repudiation, of the thinking reflected in Pink.

\section{Conflicts of Interest: National and International}

Domestic courts necessarily function as national institutions and as agents of international legal order. This much is non-controversial; the controversy arises when, as in Sabbatino, it becomes necessary to attribute significance to the reality of this dual membership in a specific instance, especially one in which contradictory lines of action emanate from national and international sources of legal authority. Then one must choose and by choosing identify which is the paramount affiliation. There is no way to compromise or otherwise avoid the thorny issue of paramountcy.

The nature of the contradiction can be illustrated by the conflict between the conduct of foreign policy and the application of a rule of international law. From the perspective of the national government, domestic courts are subordinate instruments of policy in the area of foreign relations; the executive branch has the chief responsibility and possesses the necessary authority to act on behalf of the nation. From the perspective of the international system, a court should apply rules of international law as independently and as consistently as it does rules arising from any other source of law. Domestic courts are in a position to develop international law, to manifest respect for international law, and to demonstrate that normal standards of judicial independence are just as operative in an international law case as in a domestic case. The usefulness of domestic courts as international institutions, that is, as institutions responsible for upholding international law and for displaying it as a common system of law peculiar to no single state, depends on the capacity of these courts to withstand internal political influence when

See also Cardozo, The Authority in Internal Law of International Treaties: The Pink Case, 13 Syracuse L. Rev. 544 (1962). 
confronted with an issue of international law. To the extent that domestic courts set aside the normal application of international law to serve the foreign relations of the national government, they confirm the cynical perception of international law as subordinate to or as a rationalization of national policy. In addition, if domestic courts act as a branch of the national government, their capacity to declare and develop international law is impaired. The law-giver must not appear partisan.

Yet, can the executive afford to have a domestic court impose its provincial views of the character of international law and relations upon legal controversies having important consequences for our foreign policy? The action of a domestic court is often perceived as the action of the nation as a whole, especially by those foreign nations domestically unaccustomed to an independent judiciary. Thus, if the court in state $X$ renders a decision hostile to the interests of $Y$, then $Y$ is likely to regard the judicial conduct in $\mathrm{X}$ as tantamount to a hostile foreign policy decision, a decision perhaps calling for reprisal by $\mathrm{Y}$, and certainly productive of tension. It is reasonable to maintain that, given the delicacy of the political balance in contemporary international politics, the executive needs the authority to control the behavior of courts.

The recent (February 1964) incident involving the seizure of Cuban fishing vessels on the ground that they were improperly present in the territorial waters of the United States illustrates the genuine problem that is present. The seizure itself raised tensions and led Cuba to retaliate by interfering with the normal water supply available to the United States' base at Guantanamo. In turn, this hostile Cuban act led the United States to discharge some of its Cuban employees at Guantanamo. Domestic voices in the United States were heard advocating more drastic responses, some urging a complete blockade of Cuba until Castro turned the water back on, others demanding a forcible intervention to restore the water supply. Premier Castro said that the normal supply would not be restored until the fishermen and their vessels were set free. Convinced after investigation that these vessels were being operated for fishing purposes only and were not engaged in a mission that was hostile to the United States, the Department of State apparently favored prompt release of the vessels and crews.

That action might have terminated the crisis. Florida authorities, however, wanted to prosecute these fishermen under a state statute making it a crime to fish without a license in Florida's territorial waters, a citizen of a communist state being ineligible to obtain a Florida license. The federal government turned the Cubans over to Florida authorities, enabling prosecution and conviction of the four boat captains. The ac- 
tion of the Florida courts might well have inflamed Cuban-American relations in a manner that is contrary to the will and wisdom of the State Department, although the federal decision to allow the Florida prosecution must have discounted this possibility. Does not the federal government need to retain the competence to withdraw such a case from Florida courts?

In this instance the executive possessed the original competence to deny court action because it had obtained custody over the prospective defendants. The federal government could certainly have effectively refused Florida's request since, in a criminal case where federal custody exists, initial executive control over the prosecution is assured. If instead the incident had grown out of a state enforcement action, that is, had the jurisdiction over the defendants and their vessels resulted from a Florida seizure and prosecution, one can visualize that the problems posed by the conflict between the United States' form of federalism and its foreign relations are potentially very serious.

This kind of problem is created by the political context within which any executive decision to prosecute is made. Since a criminal prosecution is a matter of executive discretion, it is, therefore, properly construed as an aspect of foreign relations. Whether a state with a federal system that involves the decentralization of executive authority should develop a competence to assure federal control is a special, although important, question. It is probably not reasonable for us to expect foreign states to accept the autonomy of our federal units as an excuse for action to which they object. On the other hand, the authority of the fifty states to apply their own law to events within their jurisdiction is an essential attribute of the federal system.

The incident involving Cuban fishing boats is interesting partly because it powerfully demonstrates why the executive might want and need to exercise control over domestic litigation in order to properly execute fundamental national policy in foreign affairs. There are special elements in the case, however, that require greater emphasis. First, the illustration concerned a criminal prosecution, i.e., a public act of the prosecuting government, that is by its discretionary nature inevitably political and thus reasonably construed as political by foreign governments. This point becomes more evident when one recalls the reaction in the United States to foreign criminal prosecutions of American servicemen, even when those prosecutions occurred in friendly states. States are habitually sensitive whenever their nations have been made defendants in a criminal prosecution, and this sensitivity is accented if the prosecution seems motivated by hostility toward the nation to which the defendants owe al- 
legiance. If there is a political background to the prosecution, it then often appears that the foreign state is the real defendant. In this regard it is hard to imagine a seizure by the Coast Guard of Mexican fishing vessels operating under circumstances similar to those of the Cuban vessels, and it is almost inconceivable to suppose a Florida prosecution after a federal willingness to release.

Second, by discriminating against certain foreign states on the basis of their political system, the underlying Florida licensing law incorporates a viewpoint toward international relations tantamount to the adoption of a foreign policy for Florida. Here again, the federalistic structure of the United States complicates the analysis. The Florida policy is not a reason for restricting the role of domestic courts, however. Rather it is a matter relating to the extent to which unified federal control is, can and should be maintained over the fifty states in order to exclude them from participating in the foreign policy-making function.

Lastly, the prosecution itself, when and if it takes place, does not necessarily involve an issue of international law. It is certainly quite possible for the defense to contend that ships traversing territorial waters are not bound to obey the subnational laws of Florida and that, in any event, the Florida licensing statute is illegal under an international rule of non-discrimination and therefore unenforceable. To the extent that a Florida prosecution involves arguments about the application of rules of international law to a dispute, the case is correctly treated as one that concerns the proper function of domestic courts.

\section{Arguments Favoring Executive Preemption}

An international law case is one in which the judicial outcome depends at least in part upon a dispute over the application or character of international law rules. If the suit was genuinely initiated by a private party, the controversy presumably does not reflect a governmental decision to prosecute. Nevertheless, it may not resemble ordinary private litigation; "complications" may arise. For example, an inconsistency may arise between the diplomatic representations of the United States and the determination of its domestic courts. If an American court finds that an expropriating state need not always pay prompt, adequate and effective compensation, it is more difficult for the State Department to maintain the contrary position. Thus, it can be argued that judicial action might prejudice diplomacy covering the same subject matter. Also it could be urged that a court is less competent than the executive to interpret rules of international law. Furthermore, since the executive must necessarily take a position when disputes about international law arise, 
it may be both confusing and embarrassing to risk an inconsistent judicial position. It can be contended with some force, therefore, that either courts should be kept silent when a controversial rule of international law is at stake, or they should interpret international law in accord with executive will to the end that the judiciary and executive branches speak with a single national voice in international law disputes. And finally, in certain situations, Bahia de Nipe for example, the executive might want to bargain a judicial release for a foreign favor; that is, the American executive branch may wish to give up its jurisdiction over a foreign ship in exchange for the return of United States' hi-jacked planes in foreign possession. ${ }^{17}$ A recognition of executive paramountcy provides a bargaining counter in international negotiations that can be valuable on certain occasions.

These considerations demonstrate that disadvantages may arise if domestic courts achieve real independence in international law cases, and that the executive may sometimes have good reason for seeking to restrain or manipulate domestic courts. Clearly, the conduct of foreign relations might be adversely affected by the treatment accorded an international law case by a domestic court, but likewise our foreign relations might be adversely affected by the investment policies of United States' corporations conducting business abroad. This potential for adverse effects must be balanced against the potential for beneficial effects. In weighing the balance, it is evident that one is faced with a problem of scheduling utilities and arranging priorities. Is it more important to encourage the independent operation of a domestic court or to assure the executive control over activity that might influence the conduct of foreign relations? In the final analysis, this question can be answered only by a value judgment. An objective comparison of the net effect of judicial autonomy versus executive control appears infeasible.

\section{Arguments Favoring Judicial Independence}

Despite the acknowledgment that values affect one's judgment about the proper role of domestic courts in the international legal order, it is possible to advance a supporting rationale for a judiciary that is independent in non-criminal and non-primitive international law cases. ${ }^{18}$

1. Purely international tribunals are not conveniently available for the litigation of disputes about international law.

2. Respect for the claims of international law as a legal system is lost if adjudication is made subservient to diplomacy.

17. Rich v. Naviera Vacuba, S.A., 295 F.2d 24 (4th Cir. 1961).

18. Only a listing of the reasons is intended here. 
3. Domestic courts have an excellent opportunity to develop international law if they will be allowed to operate as independent tribunals.

4. The domestic location of the forum should normally not be treated as an essential aspect of the controversy. The Sabbatino litigation could just as easily have taken place in a foreign forum; some of the cases testing the validity of the Iranian and Indonesian nationalization programs took place in domestic courts of countries that did not even have an interest in the expropriated property. ${ }^{19}$

5. The independence of the judiciary in international law cases is one way to shatter the illusion that sovereignty allows a state to reconcile its obligation to uphold international law with the promotion of its national interests. In fact, the depoliticalization of courts in international law cases weakens the regressive notion that states are the only significant actors in international relations.

6. An awareness by the general community of states of the independence of the judiciary will by itself mitigate many of the burdens that such independence imposes on the executive. Part of the need for executive control arises from the illusion abroad-especially in states that lack independent political institutions and a system of intra-governmental checks and balances-that executive control exists in fact, and that judicial behavior is accordingly a product of executive will.

7. An independent judiciary preserves a private sector of international transactions that is not vulnerable to government control, and thereby resists the trend toward totalization of the exercise of control over human activity by the modern state. It is desirable to allow the state to speak with several voices in foreign affairs if the effect is to resist the tendency of the public sector to take over all private, non-national activities. Application of international law by domestic courts should satisfy expectations created by law, rather than be made responsive to the needs of world politics or foreign policy.

8. Domestic courts are in a better position, in part because of their visibility and disciplined mode of operation, to resist domestic pressures to apply international law in a partisan manner. Public opinion, legislative pressures and interest groups have more opportunity to influence executive than judicial processes of decision-making.

19. Anglo-Iranian Oil Co. v. S.U.P.O.R. Co., Civil Tribunal of Venice, [1955] Int'l L. Rep. 19; Anglo-Iranian Oil Co. v. Idemitou Kosan Kabuskiki Karsha, [1953] Int'l L. Rep. 312 (High Court of Tokyo) ; Domke, Indonesian Nationalization Measures Before Foreign Courts, 54 AM. J. INT'L L. 305 (1960) (discussion of and excerpts from the opinions of the District Court in Bremen and the Hanseatic Court of Appeals in N.V. Verenigde Deli-Maatschapijen v. Deutsch-Indonesische Tabak-Handelsgesellschaft $M$. r. H.). See also Baade, Indonesian Nationalization Measures Before Foreign Courts$A$ Reply, 54 Asr. J. INT'L L. 801 (1960). 
9. Domestic courts can educate the public about the character and importance of international law by writing opinions in this area, particularly if these opinions manifest a non-political approach to the interpretation and application of rules of international law. Such communication may also help to induce the new states to accept international law as a serious source of mutual constraint.

10. The dangers of the nuclear age make it desirable to take risks, even to make sacrifices, in order to promote the growth of world legal order. The constructive use of domestic courts encourages a fuller and more responsible participation by nations in the international legal system.

\section{After Judictal Independence, Then What?}

Suppose that domestic courts do liberate themselves from executive constraints in private litigation involving the potential application of rules of international law to the contested action of foreign governments. That is, suppose a complete repudiation of the Pink tradition and an affirmation of the need for judicial independence in international law cases occur. Then what?

At first glance the effects of judicial independence appear trivial. Adherence to the act of state doctrine requires a domestic court in the United States to refrain from reviewing the validity of official action taken by a foreign government. ${ }^{20}$ For the purposes of the litigation, the foreign act of state must be treated as valid by a domestic court. Thus, even though the executive branch does not instruct the court on what it must do, the court by its own rules of deference is foreclosed from doing anything.

Judicial independence does, however, make an important difference in one respect. The executive loses the competence to suspend the operation of the act of state doctrine by writing a "Bernstein Letter."

20. For a more complete discussion of the nature and scope of the act of state doctrine, see Falk, Toward a Theory of the Participation of Domestic Courts in the International Legal Order: A Critique of Banco Nacional de Cuba v. Sabbatino, 16 Rutgers I. Rev. 1, 31-37 (1961) ; Hyde, The Act of State Doctrine, 53 AM. J. INT'L L. 635 (1959).

21. The idea of a Bernstein Letter arises from a series of cases dealing with Nazi German acts of state. These acts of state took property without compensation from Jewish owners. In Bernstein v. Van Heyghen Freres Societe Anonyme, S.A., 163 F.2d 246 (2d Cir. 1947), Judge Learned Hand held that the act of state doctrine prevented a domestic court from questioning the validity of the German confiscatory acts. A second case involving similar facts, Bernstein v. N.V. Nederlandsche-Amerikaanscheu Stoomvaart-Maatschappij, $173 \mathrm{~F} .2 \mathrm{~d} 71$ (2d Cir. 1949), also refused inquiry into the validity of the challenged German acts of state until such inquiry was authorized by a letter sent to the court by the Acting Legal Adviser to the State Department. 210 F.2d 375 (2d Cir. 1954). The letter stated that it is "the policy of the Executive, with respect to claims asserted in the United States for the restitution of identifiable property (or compensation in lieu thereof) lost through force, coercion, or duress as a result of Nazi persecution 
kind of executive competence, unrelated as it is to functional considerations of the Curtis-Wright or Waterman variety, would approve the practice of allowing ad hoc foreign policy motives to influence judicial outcomes. It is submitted that the requirements of judicial independence necessitate a repudiation of the Bernstein doctrine, ${ }^{22}$ which is, in effect, a corollary application of the Pink view of the duty of domestic courts to implement foreign policy as it was being pursued by the executive.

This does not necessarily mean that there can be no exceptions to the deference accorded by the act of state doctrine. It only means that the exceptions must be judicially created and, hence, judicially justified by reference to functional considerations. It has been advocated that the basis for an exception should be the existence of universal consensus. ${ }^{23}$ This leads to an interpretation of the external aspects of the act of state doctrine as a means of affirming the legitimate diversity of national conduct for all activity for which a common standard was not supported by a consensus. Such a view implies that the basis of obligations in international law is primarily a reflection of community will and secondarily a reflection of national will. That is, if nations are in agreement, a foreign state's conduct should be appraised by reference to the common standards; if there is a significant degree of dissensus, a domestic court should treat the disputed action of the foreign government as valid.

What makes for consensus is a difficult, but not impossible, determination. Evidence in support of or in opposition to normative standards can be ascertained by national practice, doctrinal literature and claims, as well as by the actions of states in international organizations, by the votes and proceedings of scientific legal organizations and by an examination of the technical literature. The discernment of consensus is most apparent with respect to many of the problems of human rights law; the discernment of dissensus is most salient with respect to the duty to compensate aliens for expropriated property and, generally, with respect to the law of state responsibility.

An insistence upon consensus as a basis of obligation in international law takes account of the structure of international society. There are no developed central legal organs able to change old law that conflicts with new patterns of values. Therefore, law must be administered

in Germany . . . to relieve American courts from any exercise of their jurisdiction to pass on the validity of the acts of Nazi officials." 20 State Dep'r Bull. 592 (1949). On the basis of this letter, the court in the second Bernstein case invalidated the German acts of state and awarded the property to the complainant. Cir. 1947).

22. Bernstein v. Van Heyghen Freres Societe Anonyme, S.A., 163 F.2d 246 (2d

23. See Falk, The Adequacy of Contemporary Theories of International LawGaps in Legal Thinking, 50 VA. L. REv. 231, 243-48 (1964). 
in accord with the national governmental structure that persists. The dispersion of governmental institutions on the national level and the patterns of effective control both affirm the territorial nature of law. In the absence of an overwhelming consensus to the contrary, domestic courts should accept the validity of the territorial acts of the foreign government. The act of state doctrine can be easily adapted to this set of recommendations, but the adaptation is not necessary and perhaps is even deceptive.

More useful decisions might result if courts come to justify deference or its exceptions by offering a functional account in terms of legitimate diversity and universal standards. One could dispense entirely with the act of state doctrine, although it would be necessary to attach a presumption of validity to the act of the foreign government to show it respect and thereby to restrain one's own courts from giving provincial interpretations of the character of support available for the relevant rule or rules of international law. The presumption would alert courts and litigants to the need of support for rules of international law that transcend the national outlook. In fact, it would be desirable to demonstrate the absence of any support for the claim of right implicit in the challenged action of the foreign government. This kind of demonstration would help to bring the dependence of international legal obligations upon a supporting consensus of national actors into sharper focus. If consensus be absent, the presence of diversity is tantamount to a validation of territorial law. Because international society lacks central institutions, it is important not to manipulate the concept of territory to make the foreign act extra-territorial and hence not subject to respect by a domestic court. Effectuation of the viewpoint recommended here requires a search for neutral jurisdictional formulas that associate activity with national territory in a fashion as mechanical and uniform as possible.

\section{Concluston}

There is no easy reconciliation of the national and international character of domestic courts. A functional approach based upon spheres of competence seems sensible, however, and leads to advocacy of judicial independence for domestic courts in civil litigation involving the application of rules of international law. Whatever contact such a case may happen to have with the conduct of foreign relations reflects the special character of the particular situation. The contact is not a reflection of any functional overlap, as it is when courts are asked to decide upon substantive matters that are necessarily within the sphere of foreign re- 
lations. ${ }^{24}$ Where the connection between judicial outcomes is contingent and situational rather than necessary and functional, courts should serve the cause of developing the international legal system by claiming autonomy for themselves and by rejecting all executive guidance.

But the achievement of judicial independence within the domestic system is not an invitation to domestic courts to assume an overly activist role when it becomes their duty to judge official acts of foreign sovereigns by reference to substantive rules of international law. Instead, a restrictive view of judicial function acknowledges the weakness of substantive international law in a world divided along ideological, cultural and economic lines. Accordingly, the official action of a foreign government should be treated as valid by a domestic court unless it violates a substantive rule supported actively by a global consensus of states. The absence of consensus with respect to many of the rules and standards in the area of state responsibility compels a domestic court to abstain from challenging the legality of the foreign government's official action. In this way can domestic courts operate constructively, deferring in areas of dissensus to the primacy of territorial supremacy, and implementing in other areas an existing consensus established by reference to world community standards.

24. An example is the grant of a certificate of convenience and necessity to a foreign airline or the prohibition of arms shipment to one faction in a foreign civil war. 